\title{
Pengembangan Subject Spesific Pedagogy Berbasis PBL pada Materi Pencemaran dan Kerusakan Lingkungan Untuk Penguatan Sikap Peduli Lingkungan Siswa SMP
}

\author{
Tutik Wulandari $^{1^{*}}$, Puguh Karyanto ${ }^{1}$, Baskoro Adi Prayitno ${ }^{1}$ \\ ${ }^{1}$ Program Studi Pendidikan Biologi, Fakultas Keguruan dan Ilmu Pendidikan, Universitas Sebelas Maret \\ Surakarta, 57126, Indonesia \\ *Corresponding authors: wulandaritutik023@yahoo.com
}

Manuscript received: ......... Revision accepted:

\begin{abstract}
Pada artikel ini, akan dijelaskan guideline penulisan naskah Jurnal Bio-Pedagogi Program Studi Pendidikan Biologi FKIP Research aim was to determine the characteristics, the feasibility and effectiveness of the PBL-based subject specific pedagogy to improving student caring attitudes toward the environment on the pollution and environmental damage subject matter on grade VII SMPN 2 Ngemplak academic year 2015/2016. The research is considered as Research and Development. The research design was the 4D (four-D) model by Thiagarajaan. This model consists of a problem definition phase (define), designing the product (design), development of the product (development), and dissemination of the product (disseminate). In this research the dissemination phase (disseminate) is excluded. Based on the results of this research concluded that the characteristics of PBL Based specific subject pedagogy was integrated with the pollution and environmental damage subject matter, the stages of PBL and ecological dimension of the NEP scale. The feasibility of the PBL based subject specific pedagogy in the category of feasible. The effectiveness of specific subject pedagogy can increase students' caring attitudes toward environment as shown by the value of $t$-count $>t$-table $(5.074>2.00)$.
\end{abstract}

Keywords: subject spesific pedagogy, caring attitudes toward environment, problem based learning, new ecological paradigm

\section{PENDAHULUAN}

Sikap peduli lingkungan terdiri dari tiga kata kunci yaitu sikap, peduli, dan lingkungan. Sikap adalah respon dari stimuli sosial dasar respon (Azwar, 2002). Menurut (Tim Penyusun Kamus Pusat Bahasa, 2003), peduli berarti mengindahkan, menghiraukan, memperhatikan. Lingkungan merupakan penyedia tempat dan bahan untuk kehidupan (Masruri, 2002). Sikap peduli lingkungan merupakan respon berupa kesiapan berperilaku karena adanya stimuli sosial yang mengakibatkan seseorang menghiraukan atau memperhatikan kelestarian lingkungan. Sikap peduli lingkungan perlu diterapkan secara terus menerus supaya seseorang memiliki kepribadian lingkungan yang tinggi. Sikap peduli terhadap lingkungan apabila dilakukan secara terus menerus dapat membentuk pola tingkah laku dan pola tingkah laku yang dilakukan secara berkesinambungan dapat membentuk kepribadian. Pentingnya penerapan sikap peduli lingkungan yaitu untuk membentuk kepribadian seseorang supaya memiliki rasa tanggungjawab yang tinggi terhadap kelestarian lingkungan.

Penerapan sikap peduli lingkungan dilakukan supaya bebas dari kerusakan lingkungan, dengan terciptanya lingkungan yang bersih dan sehat dapat bermanfaat untuk manusia dalam menjalankan segala aktivitas. Arti penting sikap peduli lingkungan jika diabaikan dapat berdampak negatif pada lingkungan pengelolaan alam yang tidak disertai dengan sikap peduli lingkungan memunculkan berbagai permasalahan lingkungan.

Tingkat kesadaran manusia yang rendah dapat menyebabkan kerusakan lingkungan, hal ini dapat ditunjukkan dengan perilaku membuang sampah sembarangan, membuang limbah di sungai, asap kendaraan bermotor, penebangan pohon secara sembarangan dan pemburuan hewan secara liar. Bentuk-bentuk kerusakan lingkungan yang menjadi isu global, dialami oleh Indonesia, mulai dari kerusakan hutan, kerusakan tanah, pencemaran air baik di darat maupun di laut, pencemaran udara, penipisan lapisan ozon, efek rumah kaca, hujan asam, kebisingan, penurunan keanekaragaman hayati, sampai dengan berbagai penyakit yang disebabkan atau ditularkan oleh lingkungan yang tidak sehat (Masruri, dkk. 2002).

Perilaku sadar dan peduli lingkungan (ecological behavior) dipengaruhi oleh sikap dan tanggungjawab pada lingkungan pada lingkungan yang dimediasi oleh intensi berperilaku (Kaiser et al. 1999). Perilaku ramah lingkungan muncul sebagai akibat dari kesiapan seseorang untuk bertindak terhadap lingkungan, sesuai dengan yang dikemukakan oleh Theory of Planned Behavior. Theory of Planned Behavior (Ajzen, 1991) menjelaskan bahwa perilaku ramah lingkungan muncul karena dorongan kesiapan untuk berperilaku/ behavioral intention. Salah satu faktor yang mempengaruhi kesiapan berperilaku 
adalah sikap/ behavioral attitude, yaitu sikap peduli lingkungan.

Salah satu upaya penanaman sikap peduli lingkungan dapat dilakukan melalui jenjang pendidikan. Pendidikan dianggap sebagai media yang efektif untuk menumbuhkan kesadaran dan sikap peduli terhadap lingkungan. Pendidikan karakter di sekolah hendaknya memasukkan kepedulian terhadap lingkungan alam sebagai bagian dari tema pendidikan untuk menguatkan kesadaran dan tanggung jawab sebagai warga masyarakat, warga negara, dan warga dunia (Gede Raka, dkk. 2011). Penanaman sikap peduli lingkungan di sekolah dipengaruhi oleh motivasi, guru, dan lingkungan sekolah (Wesnawa, 2004).

Konferensi Tingkat Tinggi Bumi di Rio de Janeiro tahun 1992 telah menghasilkan rumusan Agenda 21. Bab 36 bagian IV rumusan tersebut menyebutkan tentang promoting environmental education and public awareness and training. Rumusan tersebut menyatakan bahwa pendidikan memegang peranan penting dalam pencapaian visi bersama untuk mewujudkan pembangunan berkelanjutan melalui pembangunan karakter ramah lingkungan secara kultural. Pembentukan environmental ethics and attitude yang terimplementasi dalam perilaku individual terhadap lingkungan dan gaya hidup yang diikuti/sikap ramah lingkungan adalah makna komitmen dan tanggungjawab dari EfSD (Galus, 2010).

Kesiapan untuk berperilaku merupakan tolok ukur yang dapat ditetapkan sebagai indikator konatif perilaku ramah lingkungan (Ajzen, 1991). Sikap peduli lingkungan dapat diukur menggunakan instrumen skala New Ecological Paradigm (NEP) dari Dunlap, et al. (2000). Skala NEP dapat digunakan untuk mengetahui kesiapan siswa berperilaku. NEP memiliki skala pengukuran untuk mengetahui pemikiran manusia mengenai peduli-lingkungan maupun tidak peduli- lingkungan. Skala NEP terbukti sebagai alat ukur yang konsisten, karena skala $N E P$ telah diuji cobakan di beberapa penelitian pada berbagai negara untuk mengukur sikap dan perilaku peduli-lingkungan dan tidak peduli-lingkungan. Hasil revisi NEP memuat pandangan kunci yang lebih lengkap dan menggunakan istilah yang lebih baru. $N E P$ hasil revisi ini memaksimalkan content validity, sebagai satu ukuran (Dunlap, et. al., 2000). Skala NEP yang telah direvisi mencakup 15 pernyataan mengenai perilaku peduli-lingkungan dan tidak-peduli lingkungan yang merupakan hasil penjabaran dari 5 dimensi antara lain the fragility of nature balance, limits to growth, anti anthropocentrism, rejection of exemptionalism, dan eco-crisis.

Hasil angket skala NEP yang telah diisi siswa SMP N 2 Ngemplak menunjukkan bahwa sikap peduli lingkungan siswa berada pada kategori cukup dengan skor 46,03. Data sikap peduli lingkungan siswa setelah dianalisis pada setiap komponen dimensi ekologi, diketahui bahwa komponen limit to growth $(9,87)$, balance of nature $(9,68)$ dan eco-crisis $(9,62)$ berada pada kategori cukup sedangkan komponen antianthropocentrism $(8,67)$ dan anti-exemptionalism $(8,19)$ siswa berada pada kategori rendah. Hasil tersebut menunjukkan bahwa sikap kepedulian siswa masih perlu diberikan penguatan supaya siswa siap untuk berperilaku.

Hasil angket NEP siswa belum menunjukkan memiliki sikap peduli lingkungan yang tinggi. Sikap peduli lingkungan siswa dapat dikuatkan melalui materi pembelajaran siswa di sekolah. Pembelajaran lingkungan dapat diajarkan kepada siswa melalui bidang studi IPA.. Berdasarkan Kompetensi Dasar jenjang SMP, materi yang sesuai digunakan untuk meningkatkan sikap peduli lingkungan siswa adalah pada materi pencemaran dan kerusakan lingkungan.

Penerapan sikap peduli lingkungan di sekolah memerlukan desain pembelajaran yang spesifik untuk memunculkan kebiasaan atau habituasi sikap peduli lingkungan. Desain pembelajaran yang spesifik sesuai bidang studi dapat memaksimalkan kegiatan pembelajaran. Pengembangan pembelajaran yang spesifik atau subject specific pedagogy untuk membiasakan sikap peduli lingkungan pada pembelajaran IPA dengan materi pencemaran dan kerusakan lingkungan, merupakan salah satu kunci efektifitas pencapaian hasil belajar pada ranah afektif berupa perilaku peduli terhadap lingkungan.

Subject specific pedagogy merupakan pengemasan bidang studi menjadi perangkat pembelajaran yang spesifik dengan pokok bahasan tertentu. Komponen subject specific pedagogy meliputi silabus, RPP, modul, LKS dan instrument evaluasi. Pembelajaran secara spesifik perlu diterapkan dalam materi pencemaran dan kerusakan lingkungan. Desain pembelajaran yang spesifik menggunakan perangkat pembelajaran yang bersifat khusus yang berperan untuk penguatan sikap peduli lingkungan.

Berdasarkan hasil analisis perangkat yang digunakan di sekolah menunjukkan perangkat pembelajaran masih disusun secara umum. Hasil analisis dengan menggunakan matriks dimensi ekologi NEP menunjukkan perangkat pembelajaran yang digunakan sekolah belum terdapat antiexceptionalism sehingga perangkat pembelajaran yang digunakan kurang maksimal dalam memberikan penguatan sikap peduli lingkungan siswa.

Pembelajaran spesifik memerlukan model pembelajaran yang sesuai. Pendidikan lingkungan dalam proses pembelajaran dapat menggunakan beberapa model pembelajaran aktif dan inovatif yang salah satunya adalah model pembelajaran Problem Based Learning (PBL). Problem based learning merupakan salah satu model yang sering digunakan dalam pembelajaran sains termasuk biologi. PBL adalah model pembelajaran yang menjadikan masalah sebagai dasar untuk mengembangkan keterampilan pemecahan masalah, materi, konten, dan pengendalian diri (Ibrahim, 2000). Penerapan PBL dalam pembelajaran biologi memiliki kelebihan terutama 
terkait dengan melatihkan keterampilan berpikir, keterampilan menyelesaikan masalah, dan keterampilan intelektualnya (Arends, 2008). Model problem based learning merupakan model yang menyajikan permasalahan lingkungan yang berkaitan dengan kehidupan nyata untuk dapat melatih siswa dalam memecahkan permasalahan yang dapat dijumpai dalam kehidupan sehari-hari. Tan (2004) mengatakan bahwa $P B L$ dikenal sebagai pembelajaran aktif progresif dengan pendekatan yang berpusat pada siswa (student center) dimana permasalahan illstructure dalam kehidupan nyata digunakan sebagai titik awal dan dasar dalam proses pembelajaran. Model pembelajaran $P B L$ terdiri atas lima tahapan yaitu meeting the problem, problem analysis and learning issues, discoveri and reporting, discovery and reporting, solution presentation and reflection serta overview, integration and evaluation (Tan, 2003).

\section{METODE PENELITIAN}

Penelitian yang dilaksanakan merupakan penelitian pengembangan dengan menggunakan model 4-D (define, design, develop and disseminate) dari Thiagarajan, et al. (1974). Tahapan pengembangan dibatasi sampai develop. Tahap define (pendefinisian) meliputi analisis ujung depan, analisis karakteristik siswa, dan merumuskan tujuan. Kegiatan analisis ujung depan meliputi telaah kesesuaian silabus, RPP serta materi pencemaran dan kerusakan lingkungan yang terdapat pada mata pelajaran IPA kelas VII semester genap terhadap dimensi ekologi skala NEP. Analisis karakteristik siswa diketahui melalui angket New Ecological Paradigm (NEP) dan hasil observasi kegiatan pembelajaran siswa di kelas. Perumusan tujuan dilakukan untuk mengetahui tujuan pembelajaran yang akan digunakan sebagai dasar pengembangan perangkat.

Tahap design (perancangan) merupakan tahap penyusunan rancangan desain awal perangkat subject specific pedagogy berbasis PBL. Kegiatan yang dilakukan dalam tahap perancangan yaitu pemilihan format dan perancangan awal perangkat. Tahap perancangan dilakukan untuk mengembangkan perangkat SSP yang diintegrasikan dengan tahapan problem based learning dan dimensi ekologi dalam NEP untuk penguatan sikap peduli lingkungan siswa. Produk hasil tahap perancangan termasuk dalam draf I yang selanjutnya dilalukan validasi oleh ahli.

Tahap develop (pengembangan) meliputi validasi ahli, revisi I, uji coba terbatas, revisi II dan uji coba lapangan. Hasil validasi ahli dan uji coba terbatas dilakukan revisi draft kemudian disusun, selanjutnya dilakukan uji keefektifan perangkat pada uji coba subjek penelitian yang dilakukan pada siswa kelas VII B dan VII E serta guru IPA SMP Negeri 2 Ngemplak.

Analisis data penelitian melalui kegiatan analisis deskriptif untuk saran revisi dan kelayakan perangkat. Analisis hasil belajar kognitif pada siswa melalui pretest dan posttest. Analisis sikap peduli lingkungan siswa melalui angket skala NEP. Hasil belajar kognitif dan sikap peduli lingkungan siswa dianalilisis statistik menggunakan wilcoxon dan paired sample t-test. Produk pengembangan pada penelitian ini adalah perangkat pembelajajaran yang meliputi silabus, RPP, LKS, modul dan alat evaluasi berbasis $P B L$.

\section{HASIL DAN PEMBAHASAN \\ Karakteristik Subject Specific Pedagogy berbasis PBL}

Karakteristik subject specific pedagogy yang dikembangkan terdiri dari beberapa ciri yaitu integrasi tahapan problem based learning dan 5 dimensi ekologi yang terdapat pada new ecological paradigm. Tahapan PBL meliputi meeting the problem, problem analysis and lerning issues, discovery and reporting, solution presentation and reflection sampai tahap overview, integration and reflection. Tahapan meeting the problem berupa penyajian permasalahan lingkungan berdasarkan kehidupan nyata. Permasalahan yang disajikan berkaitan dengan kehidupan nyata dapat membantu siswa mengetahui berbagai penyebab dan dampak yang ditimbulkan pada lingkungan sehingga dapat memunculkan sikap peduli lingkungan (Rohmah, $d k k$. 2014). Tahapan problem analysis and learning issue berupa kegiatan menganalisis permasalahan berdasarkan kehidupan nyata. Tahapan discovery and reporting berupa kegiatan menemukan solusi permasalahan dan melaporkan hasil penyelesaian. Tahapan solution, presentation and reflection berupa kegiatan mempresentasikan hasil dari penyelesaian masalah. Tahapan overview, integration and reflection berupa kegiatan pengintegrasian konsep penting dalam pembelajaran serta meninjau kembali kekurangan dan kelebihan selama proses pembelajaran.

Setiap tahapan $P B L$ memberikan konstribusi dalam memberikan penguatan sikap peduli lingkungan siswa. Tahapan PBL dalam pembelajaran dengan menggunakan modul dapat melatih pembentukan sikap peduli lingkungan siswa (Ikha, $d k k$. 2014). Tahapan yang berpengaruh dalam pemberian penguatan sikap peduli lingkungan siswa yaitu meeting the problem. Tahap meeting the problem, siswa diberikan artikel yang berkaitan dengan permasalahan lingkungan sekitar supaya siswa dapat merumuskan permasalahan dalam pembelajaran. Permasalahan yang diberikan pada siswa berkaitan dengan kehidupan nyata dapat membantu siswa mengetahui berbagai penyebab dan dampak yang ditimbulkan pada lingkungan sehingga dapat memunculkan sikap peduli lingkungan (Rohmah, $d k k$. 2014). Pembelajaran berbasis masalah mampu meningkatkan sikap dan keterampilan siswa dalam memecahkan masalah (Teodorescu, et al., 2014). PBL dapat meningkatkan sikap siswa yang positif, pengalaman observasi untuk melihat secara langsung permasalahan lingkungan sekitar dapat meningkatkan sikap peduli siswa terhadap lingkungannya (Husna, dkk. 2013). Pembelajaran dengan model PBL menekankan siswa untuk 
cenderung aktif dalam proses pembelajaran seperti melakukan diskusi, dan tanya jawab. Keterlibatan siswa dalam pembelajaran menggunakan PBL dapat meningkatkan sikap peduli lingkungan (Khanafiyah dan Yulianti. 2013).

PBL merupakan pembelajaranyang memungkinkan siswa dapat menguatkan, memperluas, menerapkan pengetahuan dan keterampilannya baik di sekolah maupun di dalam kehidupan sehari- hari, serta dapat memecahkan berbagai permasalahan dalam dunia nyata (Husna, dkk. 2013)

Subject Spesific Pedagogy terintegrasi dengan tahapan pembelajaran $P B L$ dan dimensi ekologi yang meliputi balance of nature, limit to growth, antianthropocentrism, anti-exemptionalism dan eco-crisis (Dunlap, 2000; Amburgey \& Thoman, 2011; Ogunbode, 2014). Dimensi limit to growth berkaitan dengan materi keterbatasan sumber daya alam seperti keterbatasan hutan yang telah tereksploitasi dalam menyediakan oksigen akibat kebakaran hutan. Dimensi anti-exemptionalism berkaitan dengan materi dampak penggunaan teknologi yang merusak lingkungan dengan memberikan contoh-contoh teknologi manusia yang merusak alam Dimensi antianthropocentrism berkaitan materi pembatasan ego manusia terhadap alam dengan memberikan contoh cara menjaga lingkungan dan mencegah pencemaran. Dimensi balance of nature berkaitan dengan materi tentang keseimbangan alam mudah rusak berupa contoh-contoh keseimbangan alam yang rusak akibat ulah manusia yang mencemari lingkungan. Dimensi eco-crisis berkaitan dengan materi krisis lingkungan dan kerusakan alam yang disebabkan oleh pencemaran.

\section{Kelayakan Subject Specific Pedagogy berbasis PBL}

Produk desain awal yaitu draft I dilakukan validasi oleh validator ahli dan guru IPA. Masukan dan saran dari validator digunakan sebagai dasar revisi I. Hasil validasi draft I SSP berbasis $P B L$ menunjukkan bahwa semua komponen perangkat pada draft I yang dikembangkan berada pada kriteria layak digunakan untuk uji tahap pengembangan berikutnya dengan beberapa revisi. Hasil validasi aspek konstruk silabus dapat dilihat pada Gambar 1. dengan validator dosen dan guru menunjukkan silabus sangat layak untuk digunakan.

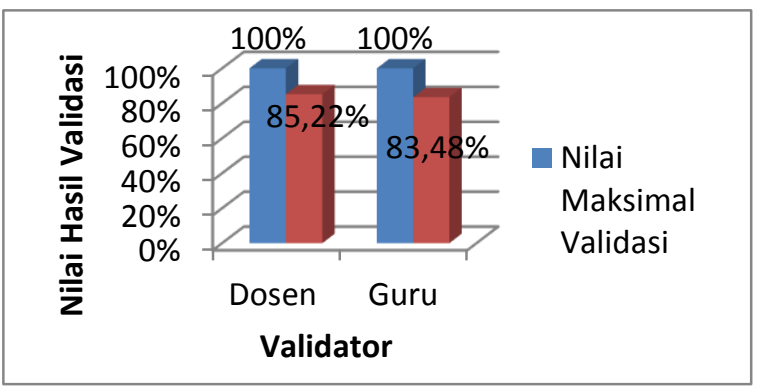

Gambar 1. Histogram Perbandingan Nilai Hasil Validasi Konstruk Silabus dan Nilai Maksimal Validasi

Hasil validasi aspek konstruk RPP dapat dilihat pada Gambar 2. dengan validator dosen dan guru menunjukkan silabus sangat layak untuk digunakan.

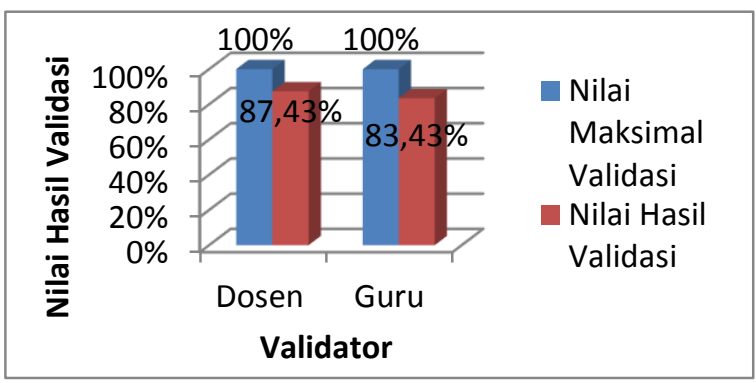

Gambar 2. Histogram Perbandingan Nilai Hasil Validasi Konstruk RPP dan Nilai Maksimal Validasi

Hasil validasi aspek konstruk RPP dapat dilihat pada Gambar 3. dengan validator dosen dan guru menunjukkan modul sangat layak untuk digunakan.

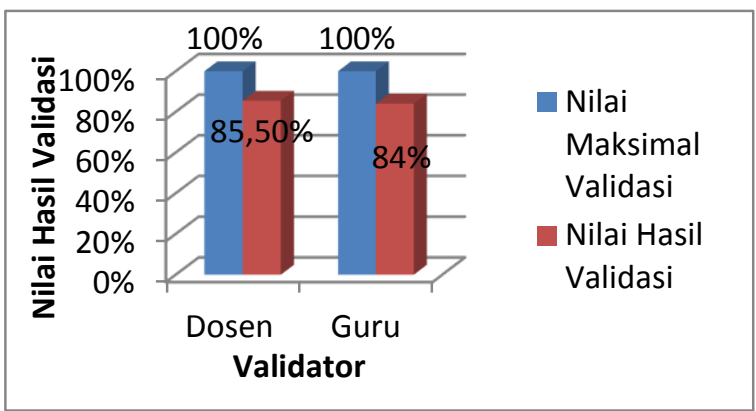

Gambar 3. Histogram Perbandingan Nilai Hasil Validasi Konstruk Modul dan Nilai Maksimal Validasi

Hasil validasi aspek konstruk LKS dapat dilihat pada Gambar 4. dengan validator dosen dan guru menunjukkan silabus sangat layak untuk digunakan.

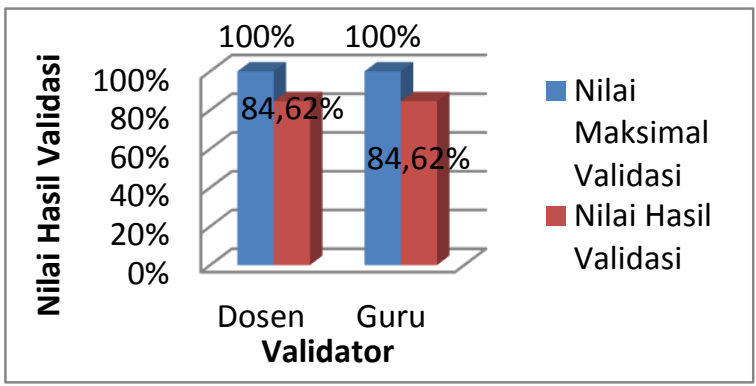

Gambar 4. Histogram Perbandingan Nilai Hasil Validasi Konstruk LKS dan Nilai Maksimal Validasi

Hasil validasi aspek konstruk soal evaluasi dapat dilihat pada Gambar 5. dengan validator dosen dan guru menunjukkan silabus sangat layak untuk digunakan. 


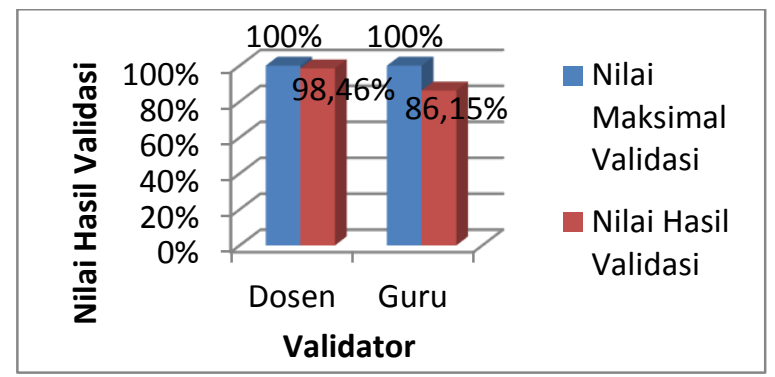

Gambar 5. Histogram Perbandingan Nilai Hasil Validasi Konstruk Soal Evaluasi dan Nilai Maksimal Validasi

Hasil validasi aspek substansi modul dapat dilihat pada Gambar 6. dengan validator ahli menunjukkan modul layak untuk digunakan.

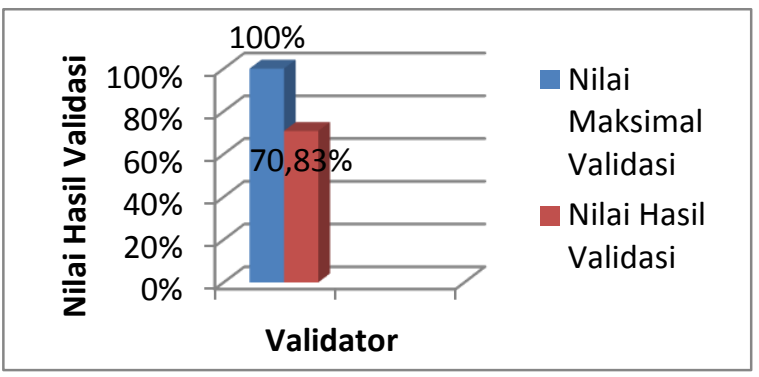

Gambar 6. Histogram Perbandingan Nilai Hasil Validasi Substansi Modul dan Nilai Maksimal Validasi.

Hasil validasi aspek bahasa modul dapat dilihat pada Gambar 7. dengan validator ahli menunjukkan modul sangat layak untuk digunakan.

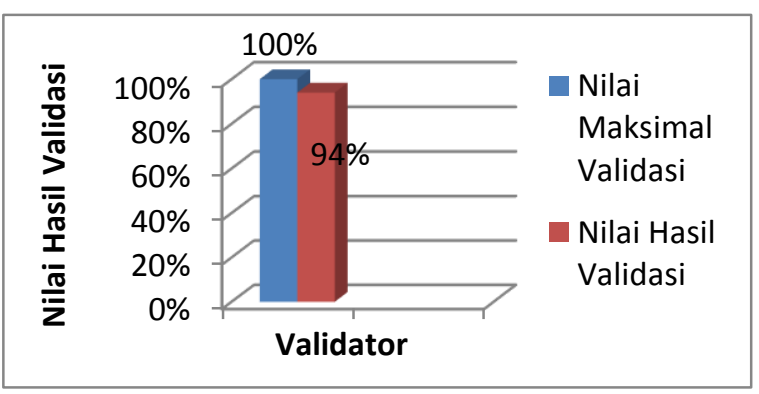

Gambar 7. Histogram Perbandingan Nilai Hasil Validasi Bahasa Modul dan Nilai Maksimal Validasi.

Hasil validasi aspek desain atau tampilan modul dapat dilihat pada Gambar 8. dengan validator ahli menunjukkan modul sangat layak untuk digunakan.

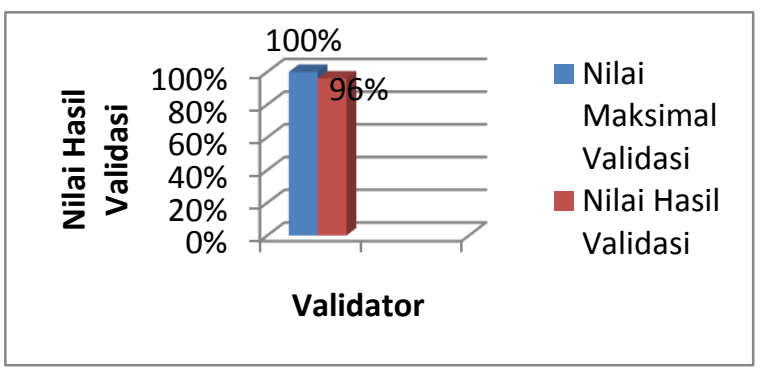

Gambar 8. Histogram Perbandingan Nilai Hasil Validasi Desain Modul dan Nilai Maksimal Validasi.

Draft I yang telah direvisi berdasarkan masukan dan saran dari validator ahli dan guru disebut draft II. Draft II dilakukan uji coba terbatas kepada lima siswa dan satu guru SMP Negeri 2 Ngemplak. Uji coba terbatas hanya dilakukan pada modul dan LKS untuk mengetahui tingkat keterbacaan modul dan LKS yang meliputi tujuan pembelajaran, materi, bahasa serta ketertarikan siswa dalam proses pembelajaran menggunakan modul dan LKS. Uji coba terbatas terhadap modul dan LKS dilakukan secara mandiri oleh siswa. Hasil rata-rata keseluruhan penilaian angket uji terbatas oleh guru dan siswa untuk perangkat modul sebesar $89 \%$ dan $87,20 \%$ dengan kriteria sangat layak. Hasil rata-rata keseluruhan penilaian angket uji terbatas oleh guru dan siswa untuk perangkat LKS sebesar $80 \%$ dengan kriteria layak dan $84,50 \%$ dengan kriteria sangat layak.

Draft II yang telah dilakukan uji coba terbatas direvisi sesuai dengan masukan dan saran pada uji coba terbatas. Draft hasil revisi II kemudian diujicobakan kepada subjek penelitian. Uji coba subjek penelitian memperoleh data hasil lembar observasi keterlaksanaan sintaks, penilaian kelayakan modul dan LKS, hasil belajar kognitif (pretest dan posttest) serta sikap peduli lingkungan siswa dengan angket skala NEP.

Penerapan subject specific pedagogy berbasis $P B L$ dilakukan di kelas VII B dan VII E dengan siswa sejumlah 63 siswa. Keterlaksanaan penerapan Subject Spesific Pedagogy berbasis Problem Based Learning dalam pembelajaran diamati menggunakan lembar keterlaksanaan sintaks pembelajaran $P B L$ oleh observer. Keterlaksanaan sintaks $P B L$ dengan mengamati kegiatan guru maupun kegiatan siswa selama proses pembelajaran mulai dari tahap meeting the problem, problem analysis and lerning issues, discovery and reporting, solution presentation and reflection sampai tahap overview, integration and reflection. Hasil observasi keterlaksanaan sintaks menunjukkan bahwa pembelajaran yang telah dilakukan pada uji coba subjek penelitian sudah sesuai dengan tahapan dalam pembelajaran $P B L$.

Hasil rata-rata keseluruhan penilaian angket uji subjek penelitian oleh guru dan siswa untuk perangkat modul sebesar $83 \%$ dan $81 \%$ dengan kriteria layak. Hasil rata-rata keseluruhan penilaian angket uji subjek penelitian oleh guru dan siswa untuk perangkat LKS sebesar $83 \%$ dan $80 \%$ dengan kriteria layak.

Berdasarkan hasil validasi, uji coba terbatas dan uji coba subjek penelitian dapat disimpulkan Subject Specific Pedagogy berbasis PBL layak untuk digunakan dalam pembelajaran materi pencemaran dan kerusakan lingkungan.

\section{Keefektifan subject specific pedagogy berbasis} $P B L$ untuk penguatan sikap peduli lingkungan Data hasil sikap peduli lingkungan angket NEP siswa meliputi nilai angket NEP siswa sebelum 
pembelajaran menggunakan $S S P$ berbasis $P B L$ dan nilai angket $N E P$ siswa setelah pembelajaran. Data hasil sikap peduli lingkungan angket NEP siswa meliputi nilai angket $N E P$ siswa sebelum pembelajaran menggunakan $S S P$ berbasis $P B L$ dan nilai angket $N E P$ siswa setelah pembelajaran Deskripsi hasil nilai angket skala $N E P$ disajikan pada Tabel 1. Hasil angket NEP pembelajaran dengan SSP berbasis $P B L$ dari ratarata 46,03 menjadi 49,13 masih dalam kategori cukup.

Tabel 1. Deskripsi Data Hasil Angket NEP Siswa

\begin{tabular}{cccccc}
\hline Jenis Angket & Jumlah Siswa & Standar Deviasi & Nilai Min & Nilai Maks & Mean \\
\hline NEP awal & 63 & 5,05 & 36 & 58 & 46,03 \\
NEP akhir & 63 & 5,05 & 38 & 62 & 49,13 \\
\hline
\end{tabular}

Data yang diperoleh kemudian dianalisis untuk mengetahui keefektifan SSP berbasis $P B L$ terhadap sikap peduli lingkungan siswa. Data awal dan akhir $N E P$ dilakukan uji prasyarat kenormalan data. Hasil uji prasyarat data hasil angket $N E P$ awal dan akhir disajikan pada Tabel 2. Berdasarkan analisis uji

Tabel 2. Hasil Uji Prasyarat Data Hasil Angket $N$ normalitas data, nilai angket $N E P$ awal dan nilai angket NEP akhir terdistribusi normal, untuk mengetahui perbedaan data awal dan akhir digunakan uji statistik parametrik paired sample t-test. Uji paired sample t-test menghasilkan data yang disajikan dalam Tabel 3.

\begin{tabular}{cccccc}
\hline Data & Uji & Jenis Uji & Hasil & Keputusan & Kesimpulan \\
\hline NEP awal & Normalitas & Kolmogorof-Smirnov & Sig $=$ & Ho diterima & Data berdistribusi \\
& & test & 0,200 & & normal \\
NEP Akhir & Normalitas & Kolmogorof-Smirnov & Sig $=$ & Ho diterima & $\begin{array}{c}\text { Data berdistribusi } \\
\text { normal }\end{array}$ \\
& & test & 0,200 & & \\
\hline
\end{tabular}

Tabel 3. Hasil Analisis NEP Awal dan NEP Akhir

\begin{tabular}{|c|c|c|c|c|}
\hline Uji & Jenis Uji & Hasil & Keputusan & Kesimpulan \\
\hline $\begin{array}{l}\text { Hasil } N E P \text { awal- } \\
\text { akhir }\end{array}$ & $\begin{array}{c}\text { paired } \\
\text { sample t-test }\end{array}$ & $\begin{array}{c}\text { Sig }=0,000 \\
t=-5,074\end{array}$ & Ho ditolak & $\begin{array}{c}\text { Ada perbedaan yang signifikan antara } \\
N E P \text { awal dan } N E P \text { akhir }\end{array}$ \\
\hline
\end{tabular}

Berdasarkan hasil uji paired sample t-test antara nilai angket NEP awal dan akhir pada subjek penelitian diperoleh taraf signifikansi $0,000<0,05$ dengan $\mathrm{t}$ hitung $=5,074>\mathrm{t}$ tabel $=2,000$ sehingga Ho ditolak dan Ha diterima. Hasil tersebut menunjukkan bahwa ada perbedaan yang signifikan antara nilai angket $N E P$ awal dan nilai angket $N E P$ akhir pada subjek penelitian.

Hasil rata-rata skor sikap peduli lingkungan siswa untuk setiap dimensi ekologi juga mengalami peningkatan pada setiap aspek yang disajikan pada

Tabel 4. Analisis Hasil Angket Setiap Dimensi
Tabel. Dimensi ekologi limit to growth mengalami kenaikan skor rata-rata dari 9,87 menjadi 10,70. Dimensi anti-anthropocentrism mengalami kenaikan skor rata-rata dari 8,67 menjadi 8,90. Dimensi balance of nature mengalami kenaikan skor rata-rata dari 9,68 menjadi 9,87. Dimensi anti-exemptionalism mengalami kenaikan dari 8,19 menjadi 8,98. Dimensi eco-crisis mengalami kenaikan dari 9,62 menjadi 10,67. Semua dimensi ekologi setelah dilakukan pembelajaran berada pada kategori cukup.

\begin{tabular}{cccc}
\hline Dimensi Ekologi Skala NEP & Sebelum & Sesudah & Selisih \\
\hline Limit to growth & 9,87 & 10,70 & 0,83 \\
\hline Balance of nature & 9,68 & 9,87 & 0,19 \\
\hline Anti-anthropocentrism & 8,67 & 8,90 & 0,23 \\
\hline Anti-excemptionalism & 8,19 & 8,98 & 0,79 \\
\hline Eco-crisis & 9,62 & 10,67 & 1,05 \\
\hline Jumlah & 46,03 & 49,13 & 3,09 \\
\hline
\end{tabular}

Hasil analisis statistik terhadap sikap peduli lingkungan siswa menunjukkan terjadi penguatan sikap peduli lingkungan siswa setelah pembelajaran. Kesiapan siswa memiliki sikap peduli lingkungan meningkat setelah pembelajaran dengan subject specific pedagogy berbasis problem based learning. Penguatan sikap peduli lingkungan siswa setelah pembelajaran termasuk dalam kategori cukup dan belum menunjukkan perilaku peduli lingkungan yang baik. Penguatan sikap peduli lingkungan siswa 
dipengaruhi oleh faktor internal dan faktor eksternal. Faktor internal berupa latar belakang pengalaman individu dan motivasi (Azwar, 2013) serta faktor eksternal berupa kondisi sosial, ekonomi dan budaya di lingkungan tempat tinggal siswa (Kollmuss \& Agyeman, 2002).

Skor NEP yang tinggi menunjukkan kesiapan siswa berperilaku juga tinggi akan tetapi nilai $N E P$ yang tinggi tidak menjamin siswa untuk berperilaku peduli lingkungan. Penerapan SSP berbasis $P B L$ dalam pembelajaran mampu memberikan penguatan sikap peduli lingkungan siswa, namun penguatan sikap tersebut masih dalam ranah kognitif siswa belum sampai berperilaku peduli lingkungan. Membangun sikap peduli lingkungan dapat melalui pembiasaan. Pembiasaan yang dapat dilakukan di sekolah dengan

Tabel 1. Deskripsi Data Hasil Belajar Kognitif Siswa

\begin{tabular}{cccccc}
\hline Jenis Tes & Jumlah Siswa & Standar Deviasi & Nilai Min & Nilai Maks & Mean \\
\hline Pretest & 63 & 14,38 & 36 & 96 & 66,10 \\
Posttest & 63 & 13,74 & 36 & 92 & 70,73 \\
\hline
\end{tabular}

Data yang diperoleh kemudian dianalisis untuk mengetahui efektivitas penggunaan perangkat SSP berbasis PBL terhadap hasil belajar kognitif. Sebelum menentukan uji yang akan digunakan, terlebih dahulu data awal (pretest) dan data akhir (posttest) diuji prasyarat kenormalan data. Hasil uji prasyarat kenormalan data dapat disajikan pada Tabel 2. Berdasarkan analisis uji normalitas data, nilai pada pretest dan posttest tidak terdistribusi normal, maka untuk menguji kesamaan digunakan uji statistik

Tabel 2. Hasil Uji Prasyarat Data Pretest dan Posttest penelitian. memasukkan konsep peduli lingkungan pada setiap kegiatan pembelajaran, melaksanakan kegiatan melestarikan lingkungan hidup, membuat slogan yang mampu menumbuhkan kebiasaan baik dalam mengelola lingkungan hidup dalam segala tingkah laku masyarakat sekolah.

Data hasil belajar kognitif siswa meliputi nilai pretest dan nilai posttest. Pretest diberikan sebelum pembelajaran dan posttest diberikan setelah pembelajaran selesai. Deskripsi data hasil belajar kognitif siswa disajikan pada Tabel 1. Hasil nilai pretest dan posttest siswa menunjukkan bahwa hasil belajar kognitif siswa mengalami peningkatan setelah pembelajaran dengan $S S P$ berbasis $P B L$ dari rata-rata 66,10 menjadi 70,73 .

nonparametrik Wilcoxon sebagai alternatif paired sample t-test. Hasil uji Wilcoxon menghasilkan data yang disajikan pada Tabel 3. Berdasarkan hasil uji Wilcoxon antara pretest dan posttest pada subjek penelitian diperoleh taraf signifikansi $0,005<0,05$ sehingga Ho ditolak dan Ha diterima. Hasil tersebut menunjukkan bahwa ada perbedaan yang signifikan antara nilai pretest dan nilai posttest pada subjek

\begin{tabular}{cccccc}
\hline Data & Uji & Jenis Uji & Hasil & Keputusan & Kesimpulan \\
\hline Pretest & Normalitas & Kolmogorof-Smirnov & Sig $=$ & Ho ditolak & Data tidak berdistribusi \\
& & test & 0,000 & & normal \\
Posttest & Normalitas & Kolmogorof-Smirnov & Sig $=$ & Ho ditolak & Data tidak berdistribusi \\
& & test & 0,000 & & normal \\
\hline
\end{tabular}

Tabel 3. Hasil Analisis Pretest dan Posttest

\begin{tabular}{|c|c|c|c|c|}
\hline Uji & Jenis Uji & Hasil & Keputusan & Kesimpulan \\
\hline $\begin{array}{l}\text { Hasil pretest- } \\
\text { posttest }\end{array}$ & Wilcoxon & Sig $=0,005$ & Ho ditolak & $\begin{array}{c}\text { Ada perbedaan yang } \\
\text { signifikan antara pretest dan } \\
\text { posttest }\end{array}$ \\
\hline
\end{tabular}

\section{SIMPULAN DAN SARAN}

Kesimpulan yang diperoleh dari penelitian pengembangan Subject Specific Pedagogy berbasis $P B L$ untuk penguatan sikap peduli lingkungan adalah sebagai berikut :

a. Karakteristik perangkat Subject Spesific Pedagogy berbasis PBL terintegrasi dengan tahapan $P B L$ dan lima dimensi ekologi NEP.

b. Kelayakan Subject Spesific Pedagogy berbasis PBL yang dikembangkan meliputi silabus, RPP, modul, LKS dan evaluasi dengan kategori layak digunakan dalam pembelajaran pada materi pencemaran dan kerusakan lingkungan.

c. Keefektifan Subject Spesific Pedagogy berbasis PBL efektif digunakan untuk memberikan penguatan sikap peduli lingkungan siswa. Rekomendasi penelitian yaitu hasil penelitian hanya dilakukan di SMP Negeri 2 Ngemplak, sehingga perlu dilakukan penyebaran di sekolah lain. 


\section{DAFTAR PUSTAKA}

Ajzen, I. (1991). The Theory of Planned Behavior. Organizational Behavior and Human Decision Processes , 179-211.

Amburgey, J. W., \& Thoman, D. B. (2011). Dimensionality of the New Ecological Paradigm: Issues of Factor Structure and Measurement. Environment and Behavior, 20 (10) , 1-22.

Arends. (2008). Learning to Teach. Yogyakarta: Pustaka Pelajar.

Azwar, S. (2002). Sikap Manusia Teori dan Pengukurannya. Yogyakarta: Pustaka Pelajar.

Azwar, S. (2013). Sikap Manusia Teori dan Pengukurannya. Yogyakarta: Pustaka Pelajar.

Dunlap, R. E. (2008). The New Environmental Paradigm Scale: From Marginality to Worldwide Use. Journal of Environmental Education, 40 (1) , 3-18.

Dunlap, R. E., Liere, K. D., Mertig, A. G., \& Jones, R. E. (2000). Endorsement of the New Ecological Paradigm: A Revised NEP Scale. Journal of Social Issues, 56 (3) , 425-442.

Galus, Ben Senang. 2010. Pendidikan Lingkungan Hidup: Untuk Sebuah Keberlanjutan Hidup Bersama. Online. http://www.pendidikandiy.go.id/dinas_v4/?view=v_artikel\& id=4, diakses tanggal 27 September 2015.

Gede Raka dkk. (2011). Pendidikan Karakter di Sekolah: Dari Gagasan ke Tindakan. Jakarta: PT Elex Media Komputindo.

Husna, S., Abdullah, \& Nurmaliah, C. (2013). Penerapan Model Problem Based Learning pada Konsep perusakan dan Pencemaran Lingkungan untuk Meningkatkan Sikap Peduli Lingkungan Siswa SMA Negeri 1 Sabang. Jurnal EduBio Tropika, 1 (2) , 61-120.

Ibrahim. (2000). Pembelajaran Kooperatif. Surabaya: Unesa-University Press.

Kaiser, F., Wolfing, S. dan Fuhrer, U. (1999). Environmental attitude dan ecological behaviour. Journal of Environmental Psychology.Vol. 19, pp. 1-19

Khanafiyah, S., \& Yulianti, D. (2013). Model Problem Based Instruction pada Perkuliahan Fisika Lingkungan untuk Mengembangkan Sikap Kepedulian Lingkungan. Jurnal Pendidikan Fisika Indonesia 9 , 35-42.

Kollmuss, A., \& Agyeman, J. (2002). Mind the Gap: why do people act environmentally and what are the barriers to pro-environmental behavior? Environmental Education Research, Vol. 8, No. 3 , 239-260.

Masruri, dkk (2002). Pendidikan Kependudukan dan Lingkungan Hidup. Yogyakarta: UNY Press.

Ogunbode, C.A. (2013). The NEP scale: measuring ecological attitudes/ worldviews in an African context. Environ Dev Sustain 15, 1477-1494.

Primarinda, Ikha. 2014. Pengembangan Modul Berorientasi Problem Based Learning (PBL) pada Materi Pencemaran Untuk Memberdayakan Kemampuan Berpikir Kritis dan Sikap Peduli Lingkungan Siswa SMA Negeri 1 Karanganyar. Prosiding Seminar Nasional Pendidikan Sains. Universitas Sebelas Maret.

Rohmah, Nofita Mittaku. 2014. Penerapan Pendekatan Salingtemas dengan Penggunaan Model Problem Based Learning untuk Meningkatkan Kemampuan Berpikir Kritis dan Sikap Peduli Lingkungan pada Siswa Kelas X MAN 2 Tulungagung. Fakultas MIPA Universitas Malang.

Setyowati, R., Parmin, dan Widiyatmoko, A. (2013). Pengembangan Modul IPA Berkarakter Peduli Lingkungan Tema Polusi sebagai Bahan Ajar Siswa SMK N 11Semarang. Unnes Science

Education Journal.

Tan, O. S. (2003). Problem Based Learning Innovation: Using Problems to Power Learning in the 21st Century. Singapore: Cengage Learning.

Tan, O. S. (2004). Enhancing Thinking Through Problem Based Learning Approaches. Singapore: Cengage Learning.

Teodorescu, R. E., Bennhold, C., Feldman, G., \& Medsker, L. (2014). Curricular Reforms that Improve Students' Attitudes and ProblemSolving Performance. European $J$ of Physics Education, 5 (1) , 15-54.

Thiagarajan, S., Semmel, D. S., \& Semmel, M. I. (1974). Instructional Development for Training Teachers of Exceptional Children Sourcebook. Indiana: Indiana University Bloomington.

Tim Penyusun Kamus Pusat Bahasa. (2003). Kamus Besar Bahasa Indonesia. Jakarta: Balai Pustaka.

Wesnawa, I Gede Astra. 2004. Menumbuhkan Kesadaran Lingkungan Melalui Pembelajaran Geografi. Jurnal Pendidikan dan Pengajaran IKIP Negeri Singaraja, No. 1 TH. XXXVII Januari 2004 